\section{B A Institute of \\ YK Business Administration \\ 六下 \\ Karachi \\ Leadership and Ideas for Tomorrow}

Business Review

Volume 16 Issue 2 July-December 2021

2022

\title{
Gold vs. PSX sectors during political uncertainties: an event study analysis
}

Hafsa Rasheed

Air University Islamabad

Habib Ahmad

Air University Islamabad

Attiya Yasmin Javid

Pakistan Institute of Development Economics

Follow this and additional works at: https://ir.iba.edu.pk/businessreview

Part of the Management Sciences and Quantitative Methods Commons, and the Portfolio and Security Analysis Commons

(c) (i)

This work is licensed under a Creative Commons Attribution 4.0 International License.

\section{Recommended Citation}

Rasheed, H., Ahmad, H., \& Javid, A. Y. (2022). Gold vs. PSX sectors during political uncertainties: an event study analysis. Business Review, 16(2), 1-20. Retrieved from https://doi.org/10.54784/1990-6587.1382

This article is brought to you by iRepository for open access under the Creative Commons Attribution 4.0 License and is available at https://ir.iba.edu.pk/businessreview/vol16/iss2/1. For more information, please contact irepository@iba.edu.pk. 


\title{
Gold vs. PSX Sectors during Political Uncertainties: An Event Study Analysis
}

\author{
Hafsa Rasheed · Habib Ahmad · Attiya \\ Yasmin Javid
}

\begin{abstract}
Amplified uncertainties in economic, financial, and political environments across nations have created a dire need to search for safe investment options that could mitigate the losses faced by investors. Consequently, researchers and investment managers have started investigating alternative investment options like real assets to cope with such risks. Since Pakistan is among the most politically unstable economies, there is a dire need to investigate this conundrum and provide Pakistani investors with alternatives. Previous researches have widely reported gold to be this alternative as it provides a hedge and safe haven during various economic downturns. Therefore, the current study investigates whether gold could also diversify the risk of political uncertainties faced by different sectors of the Pakistan stock exchange (PSX). For this purpose, initially the impact of political uncertainty on PSX sectors and gold is investigated through event study analysis, by using economically political and socio-political events from Jan 2009 to Dec 2019. Then Pearson correlation and volatility modeling using event dummies are employed to unveil the diversification characteristics of gold. Gold holds diversification characteristics in case it exhibits zero, negative or insignificant correlations with PSX sectors. Findings suggest that gold is not influenced by political events while most of the PSX sectors are influenced by socio or economical political events. The results also show that gold acts as a hedge for all sectors i.e. indicating zero correlation, and acts as a safe haven for many sectors i.e., it indicates a negative correlations, and an insignificant relationship indicating the absence of co-movement. Therefore, the study concludes that Pakistani investors could consider gold as a diversifier for diversifying traditional investment portfolios.
\end{abstract}

Hafsa Rasheed

Air University Islamabad

E-mail: hafsa_hafsa92@hotmail.com

Habib Ahmad

Air University Islamabad

Attiya Yasmin Javid

Pakistan Institute of Development Economics

(C)Rasheed, H., Ahmad, H. and Javid, Y. A. 2022 
H. Rasheed, H. Ahmad and A.Y.Javid

Keywords Gold, Political Uncertainty, Event Study, Volatility Modeling

\section{Introduction}

Political events and their negative effects on economic activities have illuminated the need to investigate the role of different assets during political uncertainties(Taimur and Khan 2013). As a result, recent political factors are among the dominating ones to be investigated by researchers(Baker et al 2016; Goodell et al 2015; Goodell and Vähämaa 2013; Huang et al 2015; Jens 2017; Liu et al 2017; Vortelinos and Saha 2016). Researchers evaluate their impact on economic growth (Kelly et al 2016), financial markets, and financial instruments(Taimur and Khan 2013.On the other hand, commodities like precious metals have attracted investors because theyre considered a safe option especially when coping with economic downturns. Thats because these assets have a minimum correlation (Rasheed et al 2021)

Moreover, among other precious metals, gold has been widely reported as a hedge and is considered a safe haven during various economic and market uncertainties(Baur and McDermott 2010; Iqbal 2017). Contributing further, the current study investigates whether gold also acts as a diversifier amid political uncertainties against PSX sectors. Thus, this research addresses the following research questions; does political uncertainty influence PSX sectors returns? If yes, then, is gold a diversifier against such political uncertainties? Furthermore, to investigate the diversification potential of gold, the study identifies if gold exhibits any correlation with PSX sectors and whether or not it acts as a hedge and a safe haven during political uncertainties.

\subsection{Political instability in Pakistan}

Based on factors like transfer of government power, armed conflicts, violent demonstrations, social unrest, terrorism, international tensions, and regional and religious conflicts, Pakistan is ranked at 189th among 195 countries for political stability by World Bank. Although it is becoming an emerging market due to its economic development in recent years, it remains politically unstable. As a result, countries like Pakistan that belong to a (politically) unstable zone, require such investigations more critically because investors face political uncertainties more frequently which results in distress and creates doubts about future returns.

Current research contributes to literature because there is rare evidence about the impact of political uncertainty on individual PSX sectors. Moreover, no previous study outlines the impact on PSX under influence of political uncertainty, and the various alternative investment/s that could save investors. Furthermore, current research contributes significantly in financial economics literature because investments under uncertainty has been a focus of portfolio optimization and asset pricing. However, some important types of risks like the 
risk of political uncertainties are still not widely addressed especially in developing countries. This study aims to fill this gap by providing a detailed and comprehensive analysis of political risk on sectors of Pakistan Stock Exchange and unveils the potential of gold as a diversifier in an environment of political uncertainty. The research also contributes to the knowledge of investors and investment managers/advisors to consider gold as an alternative investment option for their asset allocation strategy to cope with the risk of political uncertainty.

\section{Literature review}

Literature documents the impact of political uncertainties on stock returns (Kelly et al 2016; Pastor and Veronesi 2012; Taimur and Khan 2013) and also documents evidence for investigating the role of alternative investments like commodities(Iqbal 2017; Low et al 2016; Wu and Chiu 2017)to mitigate the risk of different kinds of uncertainties.

\subsection{Political uncertainty and stock returns}

Political uncertainty implies the lack of assuredness about the future outlook of governments' actions and policies(Baker et al 2016; Pastor and Veronesi 2012)and the likelihood of unanticipated political events that may affect the potential benefits of an investment (Osei-Assibey 2016). The impact of political uncertainty on asset prices, volatility and financial market movements have been documented by many empirical studies (Baker et al 2016; Jens 2017; Goodell et al 2015; Liu et al 2017; Huang et al 2015; Vortelinos and Saha 2016).

Pastor and Veronesi (2012)found stocks to be more volatile amid higher political uncertainty and argued that a risk premium is commanded by political uncertainty. Kelly et al (2016)found political uncertainty to be priced in equity option markets. Similarly, a significant drop in stock prices is documented by Liu et al (2017)during a political event, the Bo Scandal, in China. Using an event study methodology and calculating cumulative average abnormal returns (CAARs) for general as well as policy sensitive firms, a significant rise in return volatilities is found right after the event.

Political cycles are significantly associated with the movements of asset prices because governments spending policies change with the change of government, thereby resulting in significant influence on industries and their activities(Belo et al 2013). Jens (2017) documented an association of political uncertainty with firm investments. Using elections as exogenous variations of uncertainty, it is found that investments decline about 5-15 percent in firms depending on their exposure to political uncertainty because equity and debt issuances are delayed by firms before elections. Firms consider close election period closely associated with economic downturn leading to political uncertainty in the form of election results. Goodell et al (2015)stated that election predictions play an important role in predicting future returns from financial markets; therefore, prediction 
markets are widely accepted as an information aggregation vehicle for such uncertainties. Amihud and Wohl (2004) indicated that political events are significantly influential for stock prices because markets expectations change with political news. Investors positive expectations positively influence stock prices, but varying expectations are reported for pre and post-event periods(Bernile et al 2016).

\subsection{Sectors' stocks}

Different industries exhibit different reactions to varying economic (Elyasiani et al 2011) and market conditions(Arouri 2011. Studies like Arouri (2011), Choi and Hammoudeh (2010), Elyasiani et al (2011),Ramos and Veiga (2011)studied the impact of economic variations like oil price changes on industrial stocks and reported varying influences across industries. Although fluctuating economic conditions significantly influence the overall stock market (Choi and Hammoudeh 2010), the extent and direction of influence is not same across industries (He 2002). Griffin and Stulz (2001) studied the impact of exchange rate fluctuations across industries and found that although industries are prone to exchange rate fluctuations, the extent of influence is not the same. Choi and Hammoudeh (2010) illustrate that industrial stocks respond not only to financial crises but also to geopolitical crises. The sensitivity of industrial stocks to geopolitical events causes industrial returns to fluctuate in response to such events. All these studies indicate that stock returns are sensitive for changes in economic and market conditions, but different stock portfolios indicate different sensitivities towards varying conditions(Griffin and Lemmon 2002).

\subsection{Gold as a diversifier}

Over the last decade, trading in commodities as a substitute investment class in traditional portfolios has gained amplified significance, indicating commodities importance as individual investments as well as a diversifier in diversified portfolios (Batten et al 2010). Commodities are of interest for investors and investment managers because of their role in asset allocation decisions, which become more attractive during negative financial climate (Andreasson et al 2016). Commodities such as precious metals, gold and silver has gained amplified attention from investors (Batten et al 2010) due to positive returns of portfolios (Creti et al 2013).

Golds function is not limited to be a hedge and a safe haven against inflation and other economic factors, rather it could be used as a portfolio diversifier in common stock portfolios(Low et al 2016). Initially, gold company stocks are considered as diversifiers in portfolios; however, gold stocks have lost their diversification characteristics with the passage of time. Gold stocks do not offer diversification benefits like they did in 1970s, but gold bullion still has the characteristics of diversification. Therefore, gold bullion should be incorporated in 
Gold vs. PSX Sectors during Political Uncertainties...

portfolios to reap diversification benefits(Białkowski et al 2015; Chua et al 1990).

Contradictory views prevail about the hedge and safe haven characteristics of gold during uncertainties.Agyei-Ampomah et al (2014) stated that although gold provides protection to investors during negative economic conditions, in other situations like losses in sovereign bonds, it underperformed as compared to other precious and industrial metals like palladium and copper. The safe haven and hedging characteristics of gold are not consistent during varying uncertain conditions.Bredin et al (2015) revealed that gold acts as a hedge for equity investors and its safe haven characteristics are further established during financial crises periods. Iqbal (2017) found gold as a hedge against inflation and exchange rate risk. On the other hand, Baruník et al (2016) also found the heterogeneity of correlations between stocks and gold during financial turbulence and periods of economic downturn, suggesting that these could be used in diversified portfolio only for comparatively shorter durations.

Choi and Hammoudeh (2010) found decreasing conditional correlations among commodities and stock returns, indicating that they have different sensitivities to geopolitical events and crises. The declining stock-commodity correlations indicate that crises and geopolitical events have opposite impact on stocks and commodities. Researchers and asset managers emphasize that diversification benefits can be enjoyed, and investment opportunities could be improved by investors through incorporating different volatility related assets in portfolios (Chen et al 2019). Öztek and Ö̈cal (2017) suggest that diversification benefits of portfolios could be enhanced through combining stocks and commodities in portfolios rather than merely investing in stocks. Therefore, inclusion of commodities results in more diversified portfolios that are more stable across time. Hence, the above discussion indicates that gold has been investigated during various economic and market downturns, but no study indicates its behavior during political uncertainties. As a result, our study contributes significantly to literature and investors knowledge.

\section{Methodology}

\subsection{Data description and selected sample}

The study uses daily share prices of firms listed on Pakistan Stock Exchange, daily prices of Gold bullion and history of political events of Pakistan. Daily closing share prices of listed firms is collected from official website of Pakistan Stock Exchange, which is then used to calculate equally weighted sectors returns, because equal-weighted are considered to have higher exposure to systematic risk factors (Plyakha et al 2021). Data for daily gold prices (Gold Bullion Pkr. per Tola) is obtained from Goldrates.pk, while data on political events of Pakistan is collected from BBC and ABC News. Time span of current study is from 1st January 2009 to 31st December 2019. As of December 2019, there were 35 sectors listed on Pakistan stock exchange, but current study incorporates 32 sectors due to the limitation of data availability of others sectors during this time period. The names of selected sectors, their abbreviations used in 
this study, and details of included companies from each sector are presented in Appendix. Each variable contains 2719 values for daily data. Moreover, a total of 21 political events from January 2009 to December 2019 are selected.

Political uncertainty is measured through different approaches like policy uncertainty Baker et al 2016), elections (Goodell et al 2015),political news Amihud and Wohl 2004, political scandals Liu et al 2017, political crises like riots, protests (Frijns et al 2012; Huang et al 2015)budget announcement(Edirisinghe 2017; Khan et al 2017). This study considers political announcements like budget announcements, political news and change in government-either through elections or an unanticipated change due to legal verdict-as a measure of political uncertainty. An overview of selected political events is reported in Table 1.

Table 1: List of Political Events in Pakistan

\begin{tabular}{ll}
\hline Date & Event \\
\hline 11-Jun-09 & Budget Announcement \\
8-Apr-10 & 18th Amendment in Constitution. \\
19-Jun-10 & Budget Announcement \\
4-Jan-11 & Assassination of Governor of Punjab; \\
& Salman Taseer. \\
3-Jun-11 & Budget Announcement \\
19-Jun-12 & PM Yousaf Raza Gillanis Disqualifica- \\
& tion \\
11-May-13 & General Elections \\
11-Jun-13 & Budget Announcement \\
9-Sep-13 & Presidential Elections: Mamnon Hus- \\
& sain elected as president. \\
3-Jun-14 & Budget Announcement \\
13-Aug-14 & Long March and Sit-In by PTI and PAT \\
5-Jun-15 & Budget Announcement \\
15-Jun-16 & Budget Announcement \\
12-Jun-17 & Budget Announcement \\
28-Jul-17 & PM Mian Nawaz Sharifs Disqualifica- \\
& tion \\
6-Jul-18 & Nawaz Sharif sentenced to Jail \\
25-Jul-18 & General Elections \\
4-Sep-18 & Presidential Elections \\
11-Jun-19 & Budget Announcement \\
27-Oct-19 & Azadi March; Moulana Fazl ur Rehman \\
17-Dec-19 & Musharaf sentenced for death \\
\hline
\end{tabular}

Table 1 shows the political events selected based on previous relevant research; Jens (2017)pointed out that the impact of political uncertainty needs to be measured by political events such as elections, rather than a broader uncertainty index. Khan et al (2017)argued that budget announcement is part of the political event, because the government transformation has led to changes in budget policies that affect stock prices. Belo et al (2013) stated that due to the inherent uncertainty of government spending decisions related to fiscal and monetary policies, political uncertainty related to government spending policies has a significant impact on stock returns (Liu et al 2017). Goodell et al (2015) claimed that although political events such as elections are not unanticipated 
events, frequent adjustments to investor expectations due to unexpected changes in future macroeconomic policies will lead to uncertainty and volatility in the stock market.

Tirtiroglu et al (2004) believes that political events can explain the volatility pattern of the stock market because investors take a wait and see attitude due to increased political uncertainty. This uncertainty is due to the fluctuations of publics perception of upcoming political events before it actually happens. Based on all the above studies, the political events listed in Table 1 helps to capture the impact of political uncertainty in Pakistan. This table also indicates the list of selected 21 political events from January 2009 to December 2019 including two types of political events i.e. economically political events like budget announcements (9 events) (budget announcements for few years are skipped because these were overlapping with other events), and socio-political events like any political event having direct or indirect exposure to society (12 events).

\subsection{Methodologies for empirical analysis}

Appropriate methodologies play a significant role in fulfilling the purpose of study. Empirical analysis of current study starts from the calculation of assets (sectors and gold) returns. Log returns are calculated using their contemporaneous prices and previous day prices through following formula:

$$
R_{i, t}=\ln \left(\frac{P_{i, t}}{P_{i, t-1}}\right)
$$

Where $R_{i, t}$ is the normal return for asset $\mathrm{i}$ at time $\mathrm{t}, P_{i, t}$ is the current price of asset $\mathrm{i}$ at time $\mathrm{t}$, and $P_{i, t-1}$ is the previous day price of asset $\mathrm{i}$. These calculated asset returns are used for further empirical analysis.

\subsubsection{Event study analysis: impact of political uncertainty on assets}

Previous literature provides evidences of different methodologies to explore the impact of events on variables but among the most popular ones is an event study methodology which is widely used by researchers. Mahmood et al (2011), Chaudhary et al (2016) and Rosario and Chavali (2016)applied event study methodology to investigate the impact of different events on asset returns.

As discussed above and extracted from previous literature (Amihud and Wohl 2004; Baker et al 2016; Frijns et al 2012; Goodell et al 2015; Huang et al 2015; Jens 2017; Liu et al 2017), the current study measures political uncertainty through different political events. Thus, event study methodology is appropriate because it facilitates finding out the significant impact of any individual event as well as a group of events.

Business Review: (2021) 16(2):1-20 
Estimation Procedure for Event Study Initially event study methodology requires identifying the events of interest. Events of interest of current study are discussed above in table 1. After the event identification, event study is conducted through following steps:

Defining windows Event study incorporates defining three types of windows; event window, estimation window, and post event window. Event window indicates the particular days of happening of an event while estimation window indicates the time frame before the event that is used to calculate expected returns. Expected returns of estimation window are further used to calculate the abnormal or excess returns during event window for analyzing the impact of event in particular days. Post event window is used to evaluate the extent of the impact of event and see how long it takes to wipe off the impact of event. Figure 1 indicates the sequence of these windows, where 0 is the event day.

Different researchers suggest different lengths for estimation, event and post

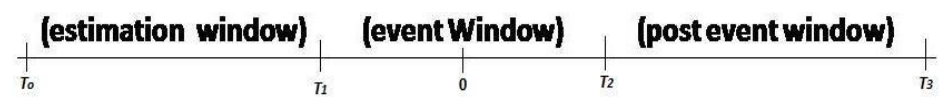

Fig. 1: Event Study Windows (Source: Authors own creation)

event windows according to the objectives of study. (Chaudhary et al (2016); Mahmood et al (2011); Pynnonen (2005); Rosario and Chavali (2016); Swarnalatha and Babu (2017)). Current study uses shorter windows due to brief time lapse between some events; some even happening within a month. So the estimation window for current study is 20 days from -4 to -24 , event window is of 7 days from -3 to +3 days and post event window is of 5 days +4 to +8 . Thus, current study is focusing on the short term effect of political events on asset returns. Baur and McDermott (2010) used 21 days to capture the impact of uncertain events.

Abnormal returns Abnormal returns are the difference between expected returns of assets and their actual returns, hence considered to be the indication of effect of the event. Assets having significant abnormal returns are considered to be influenced by the event. Expected and abnormal returns are calculated in different ways;

Market Model In market model, the expected return of assets is calculated through linear regression of asset return and the reference market return in following way:

$$
R_{i, t}=\alpha_{i}+\beta_{i} * R_{m t}+e_{i, t}
$$


Where $R_{i, t}$ is the return of asset $\mathrm{i}$ at time $\mathrm{t}, R_{m, t}$ is the market return at time $\mathrm{t}, \alpha_{i}$ is a constant, $f\left(e_{i, t}\right)$ is the error term of the model and $\beta_{i}$ indicates the sensitivity of asset return to the reference market return.Under market model, abnormal return is calculated as follows:

$$
A R_{i, t}=R_{i, t}-\left(\alpha_{i}+\beta_{i} * R_{m t}\right)
$$

Market adjusted model: In market adjusted model, return of market is considered as the expected return. Thus, the abnormal return of market adjusted model is the difference between return of asset $\mathrm{i}$ at time $\mathrm{t} R_{i, t}$ and the market return at time t $R_{m t} . f\left(E\left[R_{i}\right]\right.$ is as follows:

$$
A R_{i, t}=R_{i, t}-E\left[R_{i}\right]
$$

where

$$
E\left[R_{i}\right]=\frac{1}{n} \sum_{t=0}^{t=1} R_{i}
$$

And $\frac{1}{n} \sum_{t=0}^{t=1} R_{i}$ is the average of returns during estimation window. Current study adopts mean adjusted model because the study incorporates real asset like gold which doesnt have any reference market to calculate expected returns. Adopting the mean adjusted model, current study initially calculates expected returns from the 20 days estimation window and then abnormal returns are estimated for event and post event window. Although abnormal returns are a crucial part of event study, inferences cannot be drawn on the basis of these abnormal returns only, especially when the study incorporates multiple events. Therefore, average abnormal returns (AARs) and cumulative average abnormal returns (CAARs) are also calculated.

AARs and CAARs To highlight the significant impact of events on variables, average abnormal returns are calculated for each variable. Current study incorporates 21 political events which are categorized into two parts; economically political events (9 events) and socio political events (12 events). The average abnormal returns for each group of events are calculated by averaging the abnormal returns of asset for particular group. Formula for calculating average abnormal returns is as follows:

$$
A A R_{i}=\frac{1}{n} \sum_{i=1}^{n} A R_{i}
$$

Where $A A R_{i}$ is the average abnormal return of asset i, $A R_{i}$ is the abnormal return of asset and $\mathrm{n}$ is the number of events. The analysis of average abnormal returns facilitates highlighting whether assets generate abnormal returns during any uncertain event, thereby evidencing the impact of event on variable. Further CAARs (cumulative average abnormal returns) are estimated for each type of events for analyzing returns behavior surrounding the event. CAARs are estimated through following formula:

$$
C A A R_{i}=\sum_{i=1}^{t} A A R_{i}
$$


Where $C A A R_{i}$ is the cumulative average abnormal return of asset i, $A A R_{i}$ is the average abnormal return of asset, $\mathrm{i}$ and $\mathrm{t}$ is the time of event or post event window. The significance of CAARs allows investors to decide whether the asset generates abnormal returns during a particular event or not.

Significance test of $A A R$ s and $C A A R s$ Reliable inferences are made on the bases of significance of average abnormal returns and cumulative average abnormal returns. Various test statistics are used for testing the significance of these returns. This study makes inferences on the basis of t-statistics calculated as;

$$
t=\frac{A A R_{i} \text { or } C A A R_{i}}{S D_{i}}
$$

The calculated value of t-stats, greater than 1.96 in absolute terms or the probability value lower than 0.05 , indicates the significant impact of events on variable. Hence, significant cumulative average abnormal returns of assets help identifying the answer for the question do political uncertainties influence assets returns?

\subsubsection{Pearson correlation}

Any asset could be considered as a portfolio diversifier if it exhibits zero or negative correlation with other assets in portfolio(Baur and Lucey 2010; Theron and Van Vuuren 2018). Thats because correlation indicates the relationship between variables by specifying the change in ones magnitude causing a change in others magnitude either in opposite or same direction (Schober et al 2018). Hence, general correlation of gold with PSX sectors is explored through Pearson correlation.

\subsubsection{Volatility modeling using event dummies}

Simple correlation indicates general relationship among variables while varying relationships with surrounding conditions could be captured through volatility modeling (Baur and McDermott 2010). Moreover, the present study aims at exploring the behaviors of gold and evaluate whether it acts as a hedge or provides any safe haven to investors in comparison to traditional sectors returns, especially during uncertain political events. The goal is to guide investors about considering gold as a safe investment option to diversify the risk of political uncertainties.

GARCH Model: Hedge and Safe Haven during Political Uncertainties Current research incorporates political events as a measure of political uncertainty and (Baur and McDermott 2010) implemented the following model to investigate the safe haven and hedge characteristics of asset during crises periods;

$$
\begin{gathered}
R_{\text {asseti }, t}=a+b_{t} r_{\text {stock }, t}+e_{t} \\
b_{t}=c_{0}+c_{1} D\left(\text { event }_{1}\right)+c_{2} D\left(\text { event }_{2}\right)+\ldots+c_{n} D\left(\text { event }_{n}\right)
\end{gathered}
$$




$$
h_{i}=\pi+\alpha e_{t-1}^{2}+\beta h_{t-1}
$$

Above mentioned GARCH $(1,1)$ model captures the impact of events on asset in relation to stock market returns to indicate whether the asset co-moves with the market during uncertain events. The equation of interest in this model is equation (2), which incorporates event dummies having values 1 when returns fall in the event period and zero at all other times. Main parameters of interest are the coefficients of this mean equation (2), where parameters $c_{1}$ to $c_{n}$ indicate the presence or absence of safe haven character during particular events. If these parameters are negative; the asset acts as a strong safe haven during uncertain event. If the value is zero, it indicates that the asset is a weak safe haven. Positive values of parameters indicate that asset co-moves with the market and does not provide protection against uncertainties-thus investors should not incorporate such asset in their portfolios for diversification purpose.

The dummy variables in the above model require identifying and defining events under study-their starting date and length of time or the date of happening of an event (for one day events). Moreover, studies like the one carried out by (Iqbal 2017) also investigated the hedge and safe haven characteristics of gold incorporating an EGARCH model which allows capturing the leverage effect of volatilities during such events. Subsequently, following Baur and McDermott (2010)) and Iqbal (2017), the proposed econometric model for capturing relation of gold with sectors return during political uncertainties is an EGARCH model because descriptive statistics (skewness coefficients; see Table 2) indicate that data distribution is asymmetric and asymmetric GARCH type models like EGARCH can accommodate the asymmetric characteristics of volatility (Chen et al 2019).

$$
R_{\text {gold }, t}=\alpha+\beta_{t} R_{\text {sectori }, t}+e_{t}
$$

$$
\beta_{t}=C_{0}+C_{1} D(\text { sociopoliticalevent })+C_{2} D(\text { economicallypoliticalevent })
$$

$$
\log \left(h_{t}\right)=\omega+\phi \frac{\left|e_{t-1}\right|}{\sqrt{h_{t-1}}}+\gamma \frac{e_{t-1}}{\sqrt{h_{t-1}}}+\lambda \log \left(h_{t-1}\right)
$$

Where D indicates a time dummy having value of 1 for event day and zero otherwise. If parameters $c_{1}$ and $c_{2}$ have zero or negative values, gold is a safe haven during certain events. On the other hand, positive values of parameters indicate the co-movement of gold with particular sector, hence lacking the criteria of being a safe heaven. Dummy variables incorporated in second equation are used having an interaction with sector returns because dummy variables without interaction term would be the pure dummies; these would indicate the change in golds return in an uncertain event compared to the normal situations, but would not indicate the relationship of gold with particular sector during that event. The coefficients and t-stats of $\mathrm{c} 0$ indicate whether gold acts as a hedge for sectors, while safe haven characteristics are indicated through total effects of parameters $c_{1}$ and $c_{2}$; i.e. total effect of $c_{1}$ is the sum of $c_{0}$ and $c_{1}$ and total 
effect of $c_{2}$ is the sum of $c_{0}$ and $c_{2}$. Each parameter indicates results of particular political events. Parameter $\mathrm{c} 1$ is for socio-political events and parameter $\mathrm{c} 2$ is for economically political events. The significance of total effect of the certain parameter highlights the behavior of golds returns (weak safe haven, strong safe haven, no impact) during that event.

\section{Results and discussion}

\subsection{Descriptive statistics}

Table 2 indicates the presence or absence of $\mathrm{ARCH}$ effect in variables under study which helps to validate the implementation of proposed GARCH model if variables indicate the presence of $\mathrm{ARCH}$ effect. The table indicates that the p-value for all the variables is below 0.05, indicating the presence of ARCH effect.

Table 2: ARCH Effect

\begin{tabular}{|c|c|c|c|c|}
\hline & F-stats & $\begin{array}{l}\text { Obs. }{ }^{*} \mathbf{R}- \\
\text { squared }\end{array}$ & $\begin{array}{l}\text { Prob. } \\
\text { F }(1,2716)\end{array}$ & $\begin{array}{l}\text { Prob. Chi- } \\
\text { Square }\end{array}$ \\
\hline Gold & 49.08 & 48.24 & 0 & 0 \\
\hline AMAS & 42.35 & 41.74 & 0 & 0 \\
\hline AMPA & 581.7 & 479.4 & 0 & 0 \\
\hline CAEG & 145.6 & 138.3 & 0 & 0 \\
\hline CMNT & 14.71 & 14.64 & 0 & 0 \\
\hline CHEM & 57.62 & 56.46 & 0 & 0 \\
\hline BANK & 116.5 & 111.8 & 0 & 0 \\
\hline ENGR & 11.99 & 11.94 & 0 & 0 \\
\hline FRTZ & 3.92 & 3.92 & 0.05 & 0.05 \\
\hline FPCP & 351.1 & 311.1 & 0 & 0 \\
\hline GACR & 14.98 & 14.91 & 0 & 0 \\
\hline INSR & 383.9 & 336.6 & 0 & 0 \\
\hline INVBNK & 61.5 & 60.18 & 0 & 0 \\
\hline LEAS & 177.6 & 166.8 & 0 & 0 \\
\hline LEAT & 239.1 & 219.9 & 0 & 0 \\
\hline MISC & 21.3 & 21.15 & 0 & 0 \\
\hline MODR & 28.53 & 28.25 & 0 & 0 \\
\hline OGEC & 27.91 & 27.65 & 0 & 0 \\
\hline OGMC & 31.17 & 30.84 & 0 & 0 \\
\hline PABR & 133.3 & 127.1 & 0 & 0 \\
\hline PHRM & 38.34 & 37.84 & 0 & 0 \\
\hline PWGD & 251.2 & 230.1 & 0 & 0 \\
\hline REFN & 18.58 & 18.46 & 0 & 0 \\
\hline SUGR & 45.05 & 44.35 & 0 & 0 \\
\hline SYAR & 29.01 & 28.72 & 0 & 0 \\
\hline TECH & 10.16 & 10.13 & 0 & 0 \\
\hline TEXC & 59.01 & 57.8 & 0 & 0 \\
\hline TEXS & 106.4 & 102.4 & 0 & 0 \\
\hline TEXW & 69.42 & 67.74 & 0 & 0 \\
\hline TOBC & 4.21 & 4.21 & 0.04 & 0.04 \\
\hline TRNS & 71.3 & 69.53 & 0 & 0 \\
\hline VAAI & 116.4 & 111.7 & 0 & 0 \\
\hline WOOL & 102.3 & 98.67 & 0 & 0 \\
\hline
\end{tabular}


Gold vs. PSX Sectors during Political Uncertainties...

Table 3 reports the descriptive statistics of the daily returns of variables under study. The results indicate that gold comparatively exhibit less acute negative and positive values compare to most of the other assets under study and have comparatively lower standard deviations. Kurtosis coefficients of all variables are greater than three and skewness coefficients for most of the variables are negative, indicating that distributions of returns have fatter tails and are asymmetrical.

Table 3: Descriptive Statistics Under Study

\begin{tabular}{|c|c|c|c|c|c|c|c|}
\hline & Mean & Median & $\begin{array}{l}\text { Std. } \\
\text { Dev. }\end{array}$ & Min. & Max. & Skew. & Kurt. \\
\hline Gold & 0.0004 & 0.00042 & 0.0114 & -0.0871 & 0.0888 & -0.023 & 9.17 \\
\hline AMAS & 0.00044 & 0.00063 & 0.0156 & -0.0893 & 0.0647 & -0.145 & 4.35 \\
\hline AMPA & 0.00025 & -0.0001 & 0.0179 & -0.1459 & 0.1223 & 0.035 & 6.73 \\
\hline CAEG & 0.00013 & 0.00041 & 0.0145 & -0.0923 & 0.1185 & -0.038 & 6.28 \\
\hline CMNT & 0.00023 & -0.0004 & 0.0175 & -0.0776 & 0.1223 & 0.392 & 5.89 \\
\hline CHEM & 0.00023 & 0.00069 & 0.0121 & -0.0617 & 0.0436 & -0.369 & 4.71 \\
\hline BANK & 0.00005 & -0.0005 & 0.0141 & -0.0835 & 0.1012 & 0.174 & 7.7 \\
\hline ENGR & 0.00002 & 0.00023 & 0.0142 & -0.1008 & 0.127 & -0.002 & 9.56 \\
\hline FRTZ & 0.00023 & $-1 \mathrm{E}-05$ & 0.0151 & -0.2603 & 0.0511 & -2.018 & 35.5 \\
\hline FPCP & 0.00017 & 0.00042 & 0.0106 & -0.1599 & 0.0409 & -1.716 & 24.1 \\
\hline GACR & 0.00022 & 0 & 0.0201 & -0.1989 & 0.1846 & 0.274 & 13.3 \\
\hline INSR & -0.0002 & 0.00047 & 0.0152 & -0.331 & 0.2465 & -2.81 & 124 \\
\hline INVBK & -0.0003 & -0.0003 & 0.0194 & -0.1196 & 0.1537 & 0.195 & 8.13 \\
\hline LEAS & 0.00007 & -0.0005 & 0.0371 & -0.1961 & 0.2812 & 0.325 & 7.85 \\
\hline LEAT & 0.00041 & $-9 \mathrm{E}-05$ & 0.0273 & -0.166 & 0.228 & 0.433 & 11.1 \\
\hline MISC & 0.00018 & 0.00049 & 0.0158 & -0.159 & 0.0665 & -0.498 & 8.93 \\
\hline MODR & 0.00006 & -0.0002 & 0.0192 & -0.0989 & 0.1481 & 0.258 & 7.65 \\
\hline OGEC & 0.00051 & 0.00019 & 0.0147 & -0.1703 & 0.0487 & -0.61 & 10.9 \\
\hline OGMC & 0.00018 & -0.0003 & 0.0145 & -0.0757 & 0.1467 & 0.071 & 7.89 \\
\hline PABR & 0.00016 & 0 & 0.0208 & -0.1835 & 0.3445 & 1.675 & 45.5 \\
\hline PHRM & 0.00045 & 0.00048 & 0.0137 & -0.1022 & 0.0863 & -0.104 & 5.6 \\
\hline PWGD & 0.00003 & -0.0012 & 0.0247 & -0.1137 & 0.2208 & 0.942 & 8.84 \\
\hline REFN & $-1 \mathrm{E}-05$ & -0.0002 & 0.0215 & -0.4164 & 0.1988 & -2.646 & 58.9 \\
\hline SUGR & 0.00031 & 0.0003 & 0.0111 & -0.069 & 0.0833 & 0.116 & 6.39 \\
\hline SYAR & 0.00017 & -0.0003 & 0.0219 & -0.1488 & 0.1165 & -0.068 & 9.18 \\
\hline TECH & 0 & -0.0005 & 0.0204 & -0.2637 & 0.1215 & -0.596 & 15.4 \\
\hline TEXC & 0.00021 & $-7 \mathrm{E}-05$ & 0.0132 & -0.0783 & 0.0784 & 0.1 & 6.04 \\
\hline TEXS & 0.00015 & -0.0003 & 0.0145 & -0.1082 & 0.0913 & -0.007 & 8.38 \\
\hline TEXW & 0.00054 & 0 & 0.0257 & -0.2616 & 0.1747 & 0.098 & 13.8 \\
\hline TOBC & 0.00091 & 0.00024 & 0.0166 & -0.4355 & 0.0487 & -6.629 & 177 \\
\hline TRNS & 0.00031 & $-2 \mathrm{E}-05$ & 0.0182 & -0.0805 & 0.0942 & 0.121 & 5.22 \\
\hline VAAI & 0.00061 & 0 & 0.0233 & -0.1316 & 0.177 & 0.489 & 9.61 \\
\hline WOOL & -0.0004 & 0 & 0.026 & -0.177 & 0.155 & -0.041 & 5.73 \\
\hline
\end{tabular}

Table 3 summarizes the descriptive stats of gold and the selected sectors of PSX under study incorporating mean, median, standard deviation, minimum, maximum, skewness and kurtosis for each asset.

Business Review: (2021) 16(2):1-20 
H. Rasheed, H. Ahmad and A.Y.Javid

4.2 Event study analysis

The impact of political uncertainties on gold and sectors is indicated through significant AARs and CAARs values which are presented in Table 4. Table 4

Table 4: AARs and CAARs of Gold and PSX Sectors

\begin{tabular}{|c|c|c|c|c|c|c|}
\hline & \multicolumn{3}{|c|}{ Socio-Political } & \multicolumn{3}{|c|}{ Economically-Political } \\
\hline & AARs & CAAR & t-stats & AARs & CAAR & t-stats \\
\hline Gold & -0.0041 & -0.0062 & -0.62 & -0.0031 & -0.0033 & -0.93 \\
\hline AMAS & -0.001 & -0.0077 & $-2.16^{* *}$ & 0.0071 & 0.022 & $3.09 * * *$ \\
\hline AMPA & -0.0024 & -0.0091 & -0.64 & -0.0095 & -0.0111 & $-1.99^{* *}$ \\
\hline CAEG & 0.0005 & -0.0028 & -0.77 & -0.0022 & -0.0068 & $-1.52^{*}$ \\
\hline CMNT & 0.0112 & 0.0111 & 0.64 & -0.0006 & 0.0024 & 0.3 \\
\hline CHEM & 0.0028 & -0.0013 & -0.38 & -0.0044 & 0.0044 & 0.63 \\
\hline CEMF & 0.0169 & 0.0211 & 1.12 & -0.0125 & 0.0142 & 1.18 \\
\hline BANK & 0.0067 & 0.0151 & $2.11^{* *}$ & -0.003 & -0.0001 & -0.02 \\
\hline ENGR & 0.0048 & 0.0069 & 0.73 & -0.0034 & -0.0068 & $-2.05^{* *}$ \\
\hline FRTZ & 0.0064 & 0.0079 & $1.86^{* *}$ & -0.0019 & 0.0021 & 0.44 \\
\hline FPCP & 0.0019 & -0.0027 & -0.73 & -0.0008 & -0.0026 & -1.11 \\
\hline GACR & 0.0108 & 0.0164 & $2.06^{* *}$ & 0.003 & -0.0035 & -0.31 \\
\hline INSR & 0.0029 & 0.0032 & 1.07 & -0.0001 & 0.0104 & $3.27 * * *$ \\
\hline INVBK & 0.01228 & 0.0168 & 1.05 & -0.011 & 0.0034 & 0.46 \\
\hline LEAS & 0.0153 & 0.0113 & 0.66 & 0.0059 & 0.047 & $3.01^{* * * *}$ \\
\hline LEAT & -0.0061 & -0.0654 & $-1.77 * *$ & 0.0199 & 0.0198 & $1.44^{*}$ \\
\hline MISC & 0.0021 & 0.0106 & $1.41^{*}$ & -0.0066 & 0.0096 & $1.96^{* *}$ \\
\hline MODR & -0.0019 & 0.0013 & 0.18 & -0.0014 & 0.0072 & $1.98^{* *}$ \\
\hline OGEC & 0.0087 & 0.0224 & $2.98 * * *$ & -0.0031 & -0.0039 & -0.46 \\
\hline OGMC & 0.0066 & 0.014 & $2.13^{* *}$ & -0.0042 & 0.0085 & $1.84^{* *}$ \\
\hline PABR & 0.0017 & 0.0037 & 0.59 & -0.0026 & -0.015 & -0.82 \\
\hline PHRM & 0.0082 & 0.002 & 0.27 & -0.0019 & 0.0115 & $2.60 * * *$ \\
\hline PWGD & 0.0192 & 0.0391 & 1.02 & -0.0052 & 0.0101 & 0.43 \\
\hline REFN & 0.0055 & 0.0173 & $2.30 * *$ & -0.0011 & 0.0065 & 0.9 \\
\hline SUGR & 0.0016 & -0.006 & -1.05 & -0.0013 & -0.0063 & -1.08 \\
\hline SYAR & 0.009 & 0.0017 & 0.24 & -0.0016 & -0.0011 & -0.11 \\
\hline TECH & 0.0041 & 0.0135 & 0.99 & -0.0063 & -0.0108 & -1.64 \\
\hline TEXC & 0.0099 & 0.004 & 0.88 & 0.0028 & 0.0044 & 1.11 \\
\hline TEXS & 0.0017 & 0.0035 & 0.58 & 0.0051 & 0.0018 & 0.2 \\
\hline TEXW & 0.004 & -0.0022 & -0.49 & 0.0003 & 0.0113 & $1.63^{*}$ \\
\hline TOBC & 0.0014 & 0.002 & 0.41 & -0.0051 & -0.0054 & -1.3 \\
\hline TRNS & 0.0044 & 0.0119 & $1.58^{*}$ & -0.0039 & 0.0055 & 0.81 \\
\hline VAAI & -0.0008 & -0.0109 & -0.92 & 0.0002 & 0.0132 & 0.9 \\
\hline WOOL & 0.0085 & 0.0318 & $1.73^{* *}$ & -0.0025 & -0.024 & -1.22 \\
\hline
\end{tabular}

shows that neither socio-political nor economically political events have any significant influence on gold.There are also some sectors of Pakistan Stock Exchange that are safe from the impact of both types of political uncertainties including Cement, Chemical, Food and Personal Care Products, Paper and Board, Power Generation and Distribution, Sugar, Synthetic and Rayon, Technology and Communication, Textile Composite, Textile Spinning, Tobacco, and Vanaspati and Allied Industries. Socio-political events are found to be significantly influential for Commercial Banks, Fertilizers, Glass and Ceramics, Oil and Gas Exploration Companies, Refinery, Transport and Woolen sectors while 
economically political events are significantly influential for Automobile Parts and Accessories, Cable and Electric Goods, Engineering, Insurance, Leasing, Modarabas, Pharmaceutical and Textile Weaving sectors. On the other hand, Automobile Assembler and Parts, Leather and Tanneries, Miscellaneous, and Oil and Gas Marketing Companies are influenced by both types of political uncertainties. Results reported in the above table indicate that political uncertainties, in either type, influence most of the sectors of Pakistan Stock Exchange causing distress for investors. Since gold is safe from such influences, it could provide some protection to investors from losses caused by such uncertainties.

\subsection{Pearson correlation}

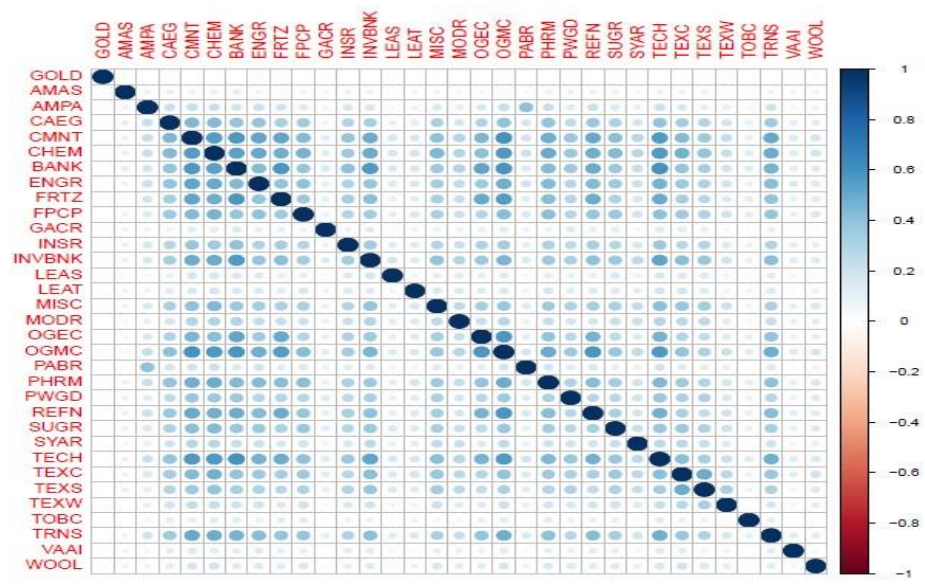

Fig. 2: Pearson correlation of Gold with PSX sectors

Figure 2 shows that gold exhibits either negative or almost zero correlations with all PSX sectors under study indicating golds diversification characteristics. Further properties of gold are unveiled by investigating its hedge and safe haven characteristics during political uncertainties to find whether it should be considered as a portfolio diversifier by investors.

4.4 Volatility modeling: hedge and safe haven characteristics of gold

Table 5 incorporates the results for hedge and safe haven characteristics of gold against each sector. The coefficient value indicates the hedge, total effect indicates the safe haven characteristics, while total effect is the sum of coefficient and particular parameter.

Business Review: (2021) 16(2):1-20 
H. Rasheed, H. Ahmad and A.Y.Javid

Table 5: Hedge and Safe Haven Characteristics of Gold

\begin{tabular}{|c|c|c|c|}
\hline & $\begin{array}{l}\text { Coef. } \\
\text { (p-value) }\end{array}$ & $\begin{array}{l}\text { EPE T. effect } \\
\text { (p-value) }\end{array}$ & $\begin{array}{l}\text { SPE T. effect } \\
\text { (p-value) }\end{array}$ \\
\hline AMAS & $0.00(.022)^{* *}$ & $-0.117(.592)$ & $-0.123(.529)$ \\
\hline AMPA & $0.00(.021) * *$ & $0.059(.775)$ & $-0.310(.078)^{*}$ \\
\hline CAEG & $0.00(.022) * *$ & $0.001(.997)$ & $-0.055(.772)$ \\
\hline CMNT & $0.00(.018) * *$ & $0.018(.935)$ & $-0.152(.257)$ \\
\hline CHEM & $0.00(.017) * *$ & $0.085(.690)$ & $-0.587(.061)^{*}$ \\
\hline CEMF & $0.00(.022) * *$ & $0.037(.829)$ & $0.035(.770)$ \\
\hline BANK & $0.00(.022) * *$ & $0.011(.983)$ & $0.039(.811)$ \\
\hline ENGR & $0.00(.021) * *$ & $-0.056(.729)$ & $-0.168(.360)$ \\
\hline FRTZ & $0.00(.019) * *$ & $0.005(.988)$ & $-0.298(.044)^{* *}$ \\
\hline FPCP & $0.00(.020) * *$ & $0.063(.915)$ & $-0.352(.057)^{*}$ \\
\hline GACR & $0.00(.025) * *$ & $-0.201(.337)$ & $0.039(.809)$ \\
\hline INSR & $0.00(.024) * *$ & $-0.006(.987)$ & $0.207(.446)$ \\
\hline INVBNK & $0.00(.022) * *$ & $0.066(.616)$ & $0.032(.849)$ \\
\hline LEAS & $0.00(.021) * *$ & $0.022(.947)$ & $-0.057(.296)$ \\
\hline LEAT & $0.00(.019) * *$ & $-0.169(.313)$ & $-0.350(.242)$ \\
\hline MISC & $0.00(.021)^{* *}$ & $0.082(.607)$ & $0.209(.267)$ \\
\hline MODR & $0.00(.023) * *$ & $0.106(.736)$ & $-0.013(.941)$ \\
\hline OGEC & $0.00(.022)^{* *}$ & $0.027(.958)$ & $0.056(.741)$ \\
\hline OGMC & $0.00(.021) * *$ & $0.046(.925)$ & $-0.210(.170)$ \\
\hline PABR & $0.00(.019) * *$ & $0.063(.853)$ & $0.146(.604)$ \\
\hline PHRM & $0.00(.025) * *$ & $-0.002(.994)$ & $-0.294(.022)^{* *}$ \\
\hline PWGD & $0.00(.021) * *$ & $-0.083(.576)$ & 0.019 \\
\hline REFN & $0.00(.020) * *$ & $-0.006(.981)$ & $-0.112(.261)$ \\
\hline SUGR & $0.00(.021) * *$ & $0.004(.994)$ & $-0.118(.675)$ \\
\hline SYAR & $0.00(.021) * *$ & $-0.083(.576)$ & $-0.275(.078)^{*}$ \\
\hline TECH & $0.00(.021) * *$ & $0.016(.956)$ & $0.071(.660)$ \\
\hline TEXC & $0.00(.022) * *$ & $-0.035(.915)$ & $-0.072(.624)$ \\
\hline TEXS & $0.00(.022) * *$ & $-0.058(.810)$ & $0.140(.454)$ \\
\hline TEXW & $0.00(.021)$ ** & $0.084(.629)$ & $0.081(.420)$ \\
\hline TOBC & $0.00(.020) * *$ & $-0.011(.976)$ & $-0.075(.545)$ \\
\hline TRNS & $0.00(.022) * *$ & $-0.020(.944)$ & $-0.007(.948)$ \\
\hline VAAI & $0.00(.020)^{* *}$ & $-0.095(.945)$ & $-0.047(.784)$ \\
\hline WOOL & $0.00(.030) * *$ & $0.024(.891)$ & $-0.093(.091)^{*}$ \\
\hline
\end{tabular}

$* * * 1 \%, * * 5 \%, * 10 \%$ critical values.EPE $=$ economically political events, SPE $=$ Sociopolitical events.

Table 5 indicates that the hedge coefficients for all sectors under study are significant at 5 percent significant level indicating that Gold acts as a hedge for PSX sectors. Total effects of economically political events for all sectors and of socio-political events for most of the sectors are not found to be significant depicting that gold does not act as a safe haven for most of the sectors under study. Total effects of socio-political events for Automobile Parts and Accessories, Chemical, Fertilizer, Food and Personal Care Products, Pharmaceuticals, Synthetic and Rayon, and Woolen sectors are found to be significant and negative, implying that gold acts as a safe haven for these sectors during socio-political events. Results reported in table 5 indicate that gold not only acts as a hedge for PSX sectors in normal conditions, but it also acts as a safe haven during political uncertainties for many sectors listed on Pakistan Stock Exchange. These findings are consistent with the findings of Ahmad et al (2017),Akbar et al (2019),Aftab et al (2019),Iqbal (2017), and Rasheed et al 
(2021)indicating the hedge and safe haven characteristics of gold during various economic, market and political uncertainties in Pakistan.

According to Baur and McDermott (2010), assets are the best diversifiers when they hold little or no correlations with other assets in the portfolio. Based on such findings, the results of current study indicate the diversification potential of gold; zero values for hedge coefficients, negative values for total effects and all other insignificant values clearly indicate that gold doesn't exhibit any correlation with most of the sectors of PSX except for some where it holds negative correlations. These findings indicate that in Pakistan, gold does not co-move with the sectors of PSX suggesting that if these sectors are hit by political uncertainties leading to loss of investment returns, then gold can provide them protection in such circumstances. Therefore, incorporating gold in their asset allocation strategy could generate diversification benefits for Pakistani investors. Findings suggest that investors investing in Pakistan Stock Exchange, or any sector, must consider gold as a diversifier to design a best diversified portfolio.

\section{Conclusion}

Highly (politically) unstable economies create highly uncertain investment environment as well; subsequently, investors in such economies always seek for some safe investment options. As Pakistan is among one of the most (politically) unstable economies, its crucial that Pakistani investors be aware of which sectors of the Pakistan Stock Exchange are more prone to the risk of political uncertainties and which safe alternative to use to diversify such risk. In this regard, the current study explored the impact of political uncertainties on sectors of PSX and Gold using event study analysis. The properties of gold as a diversifier are investigated through volatility modeling to see if it acts as a hedge and safe haven for different sectors of Pakistan Stock Exchange. Impact of political uncertainties is investigated through two types of political events; economically political events like budget announcements and socio-political events that have a direct or indirect impact on society. Event study analysis indicate that gold is not influenced by any type of political events under study while most of the sectors of Pakistan Stock Exchange are significantly influenced by either socio-political events, economically political events or both. Sectors that are an exception to the political uncertainty include Cement, Chemical, Food and Personal Care Products, Paper and Board, Power Generation and Distribution, Sugar, Synthetic and Rayon, Technology and Communication, Textile Composite, Textile Spinning, Tobacco, and Vanaspati and Allied Industries.

Volatility modeling indicates that Gold acts as a hedge for all sectors under study and it also acts as a safe haven for Automobile Parts and Accessories, Chemical, Fertilizer, Food and Personal Care Products, Pharmaceuticals, Synthetic and Rayon, and Woolen sectors for socio-political events. Zero values for hedge coefficients and negative significant values of total effects indicate that gold doesnt hold any significant correlation with most of the sectors of Pakistan Stock Exchange. The insignificant values indicate that it does not co- 
move with the other assets under study during such uncertainties. According to Baur and McDermott (2010), asset exhibiting insignificant relationship indicates the absence of co-movement with the other asset so it could be considered as a diversifier. Hence, results indicate that gold could be considered as a best diversifier for diversifying the risk of political uncertainties in Pakistan. Findings suggest that investors in Pakistan must hold highly diversified portfolios by incorporating real assets like gold that provide diversification benefits during political uncertainties. As most of the sectors are prone to the risk of political uncertainties, investors should not just rely on stock investments; rather, they must consider other safe assets like gold for diversification purpose so that if stock exchange is hit by political events and they face loss in their returns, it can be mitigated by gold returns.

\section{References}

Aftab M, Shah SZA, Ismail I (2019) Does gold act as a hedge or a safe haven against equity and currency in asia? Global Business Review 20(1):105-118

Agyei-Ampomah S, Gounopoulos D, Mazouz K (2014) Does gold offer a better protection against losses in sovereign debt bonds than other metals? Journal of Banking \& Finance 40:507-521

Ahmad W, Khan N, Usman A, Ahmad F, Khalil Y (2017) Stock market reaction to political event'sit-in'(evidence from pakistan). Journal of Managerial Sciences 11(1)

Akbar M, Iqbal F, Noor F (2019) Bayesian analysis of dynamic linkages among gold price, stock prices, exchange rate and interest rate in pakistan. Resources Policy 62:154-164

Amihud Y, Wohl A (2004) Political news and stock prices: The case of saddam hussein contracts. Journal of banking \& Finance 28(5):1185-1200

Andreasson P, Bekiros S, Nguyen DK, Uddin GS (2016) Impact of speculation and economic uncertainty on commodity markets. International review of financial analysis 43:115-127

Arouri MEH (2011) Does crude oil move stock markets in europe? a sector investigation. Economic Modelling 28(4):1716-1725

Baker SR, Bloom N, Davis SJ (2016) Measuring economic policy uncertainty. The quarterly journal of economics 131(4):1593-1636

Baruník J, Kočenda E, Vácha L (2016) Gold, oil, and stocks: Dynamic correlations. International Review of Economics \& Finance 42:186-201

Batten JA, Ciner C, Lucey BM (2010) The macroeconomic determinants of volatility in precious metals markets. Resources Policy 35(2):65-71

Baur DG, Lucey BM (2010) Is gold a hedge or a safe haven? an analysis of stocks, bonds and gold. Financial Review 45(2):217-229

Baur DG, McDermott TK (2010) Is gold a safe haven? international evidence. Journal of Banking \& Finance 34(8):1886-1898

Belo F, Gala VD, Li J (2013) Government spending, political cycles, and the cross section of stock returns. Journal of Financial Economics 107(2):305-324

Bernile G, Hu J, Tang Y (2016) Can information be locked up? informed trading ahead of macro-news announcements. Journal of Financial Economics 121(3):496-520

Białkowski J, Bohl MT, Stephan PM, Wisniewski TP (2015) The gold price in times of crisis. International Review of Financial Analysis 41:329-339

Bredin D, Conlon T, Potì V (2015) Does gold glitter in the long-run? gold as a hedge and safe haven across time and investment horizon. International Review of Financial Analysis 41:320-328

Chaudhary G, Hashmi SH, Younis A (2016) Does dividend announcement generate market signal? evidence from pakistan. International Journal of Economics and Financial Issues $6(1): 65-72$

Chen H, Zhang J, Tao Y, Tan F (2019) Asymmetric garch type models for asymmetric volatility characteristics analysis and wind power forecasting. Protection and Control of Modern Power Systems 4(1):1-11 
Choi K, Hammoudeh S (2010) Volatility behavior of oil, industrial commodity and stock markets in a regime-switching environment. Energy policy 38(8):4388-4399

Chua JH, Sick G, Woodward RS (1990) Diversifying with gold stocks. Financial Analysts Journal 46(4):76-79

Creti A, Joëts M, Mignon V (2013) On the links between stock and commodity markets' volatility. Energy Economics 37:16-28

Edirisinghe C (2017) Impact of government budget announcement on stock market sector indices: Evidence from colombo stock exchange. Journal of Finance and Accounting $5(6): 214-218$

Elyasiani E, Mansur I, Odusami B (2011) Oil price shocks and industry stock returns. Energy Economics 33(5):966-974

Frijns B, Tourani-Rad A, Indriawan I (2012) Political crises and the stock market integration of emerging markets. Journal of Banking \& Finance 36(3):644-653

Goodell JW, Vähämaa S (2013) Us presidential elections and implied volatility: The role of political uncertainty. Journal of Banking \& Finance 37(3):1108-1117

Goodell JW, McGroarty F, Urquhart A (2015) Political uncertainty and the 2012 us presidential election: A cointegration study of prediction markets, polls and a stand-out expert. International Review of Financial Analysis 42:162-171

Griffin JM, Lemmon ML (2002) Book-to-market equity, distress risk, and stock returns. The Journal of Finance 57(5):2317-2336

Griffin JM, Stulz RM (2001) International competition and exchange rate shocks: a crosscountry industry analysis of stock returns. The review of Financial studies 14(1):215-241

He LT (2002) Excess returns of industrial stocks and the real estate factor. Southern Economic Journal pp 632-645

Huang T, Wu F, Yu J, Zhang B (2015) International political risk and government bond pricing. Journal of Banking \& Finance 55:393-405

Iqbal J (2017) Does gold hedge stock market, inflation and exchange rate risks? an econometric investigation. International Review of Economics \& Finance 48:1-17

Jens CE (2017) Political uncertainty and investment: Causal evidence from us gubernatorial elections. Journal of Financial Economics 124(3):563-579

Kelly B, Pástor L, Veronesi P (2016) The price of political uncertainty: Theory and evidence from the option market. The Journal of Finance 71(5):2417-2480

Khan S, Baig N, Usman M, Shaique M, Shaikh R (2017) Stock market dynamics in pakistan: What do political events and budget announcements disclose? Research Journal of Finance and Accounting 8(10):113-123

Liu LX, Shu H, Wei KJ (2017) The impacts of political uncertainty on asset prices: Evidence from the bo scandal in china. Journal of financial economics 125(2):286-310

Low RKY, Yao Y, Faff R (2016) Diamonds vs. precious metals: what shines brightest in your investment portfolio? International Review of Financial Analysis 43:1-14

Mahmood S, Sheikh MF, Ghaffari A (2011) Dividend announcements and stock returns: An event study on karachi stock exchange. Interdisciplinary journal of contemporary research in business 3(8):972-981

Osei-Assibey K (2016) Price of political uncertainty: Evidence from ghanaian treasury bills. International Journal of Economics and Financial Issues 6(4)

Öztek MF, Öcal N (2017) Financial crises and the nature of correlation between commodity and stock markets. International Review of Economics \& Finance 48:56-68

Pastor L, Veronesi P (2012) Uncertainty about government policy and stock prices. The journal of Finance 67(4):1219-1264

Plyakha Y, Uppal R, Vilkov G (2021) Equal or value weighting? implications for asset-pricing tests. In: Financial Risk Management and Modeling, Springer, pp 295-347

Pynnonen S (2005) On regression based event study. Acta Wasaensia 143(2):327-354

Ramos SB, Veiga H (2011) Risk factors in oil and gas industry returns: International evidence. Energy Economics 33(3):525-542

Rasheed H, Ahmad H, Javid AY (2021) Is gold a hedge and safe haven during political uncertainties? Business and Economic Review 13(2):1-27

Rosario S, Chavali K (2016) Market reaction on dividend announcement in oman-an event study methodology. International Journal of Economics and Financial Issues 6(1)

Schober P, Boer C, Schwarte LA (2018) Correlation coefficients: appropriate use and interpretation. Anesthesia \& Analgesia 126(5):1763-1768

Business Review: (2021) 16(2):1-20 
Swarnalatha C, Babu K (2017) Stock price reaction to dividend announcement on select banking stocks. Asian Journal of Research in Social Sciences and Humanities 7(1):10431058

Taimur M, Khan S (2013) Impact of political and catastrophic events on stock returns. Available at SSRN 2528116

Theron L, Van Vuuren G (2018) The maximum diversification investment strategy: A portfolio performance comparison. Cogent Economics \& Finance 6(1):1427,533

Tirtiroglu D, Bhabra HS, Lel U (2004) Political uncertainty and asset valuation: Evidence from business relocations in canada. Journal of banking \& finance 28(9):2237-2258

Vortelinos DI, Saha S (2016) The impact of political risk on return, volatility and discontinuity: Evidence from the international stock and foreign exchange markets. Finance Research Letters 17:222-226

Wu CC, Chiu J (2017) Economic evaluation of asymmetric and price range information in gold and general financial markets. Journal of International Money and Finance 74:53-68 
Gold vs. PSX Sectors during Political Uncertainties...

Table 6: Appendix: Description of Sectors Under Study

\begin{tabular}{|c|c|c|c|}
\hline $\begin{array}{l}\text { Name of Sec- } \\
\text { tor }\end{array}$ & Abbr. & Tot. Cos & Included \\
\hline $\begin{array}{l}\text { Automobile As- } \\
\text { sembler }\end{array}$ & AMAS & 12 & 12 \\
\hline $\begin{array}{l}\text { Automobile parts } \\
\& \text { accessories }\end{array}$ & AMPA & 10 & 10 \\
\hline $\begin{array}{l}\text { Cable and } \\
\text { electric goods }\end{array}$ & CAEG & 7 & 7 \\
\hline Cement & CMNT & 22 & 20 \\
\hline Chemical & CHEM & 27 & 27 \\
\hline $\begin{array}{l}\text { Commercial } \\
\text { banks }\end{array}$ & BANK & 21 & 21 \\
\hline Engineering & ENGR & 18 & 14 \\
\hline Fertilizer & FRTZ & 6 & 6 \\
\hline $\begin{array}{l}\text { Food \& personal } \\
\text { care products }\end{array}$ & FPCP & 24 & 16 \\
\hline $\begin{array}{l}\text { Glass and Ce- } \\
\text { ramics }\end{array}$ & GACR & 9 & 9 \\
\hline Insurance & INSR & 29 & 24 \\
\hline $\begin{array}{l}\text { Inv. Banks/ Inv. } \\
\text { Cos./ Securities }\end{array}$ & INVBK & 28 & 25 \\
\hline $\begin{array}{l}\text { Cos. } \\
\text { Jute }\end{array}$ & JUTE & 2 & 0 \\
\hline $\begin{array}{l}\text { Leasing compa- } \\
\text { nies }\end{array}$ & LEAS & 10 & 8 \\
\hline $\begin{array}{l}\text { Leather \& tan- } \\
\text { neries }\end{array}$ & LEAT & 5 & 4 \\
\hline Miscellaneous & MISC & 23 & 18 \\
\hline Modarabas & MODR & 30 & 22 \\
\hline $\begin{array}{l}\text { Oil and gas } \\
\text { exploration com- } \\
\text { panies }\end{array}$ & OGEC & 4 & 4 \\
\hline $\begin{array}{l}\text { Oil and gas } \\
\text { marketing com- } \\
\text { panies }\end{array}$ & OGMC & 8 & 8 \\
\hline Paper and board & PABR & 10 & 8 \\
\hline Pharmaceutical & PHRM & 12 & 11 \\
\hline $\begin{array}{l}\text { Power generation } \\
\text { and distribution }\end{array}$ & PWGD & 19 & 19 \\
\hline Refinery & REFN & 4 & 4 \\
\hline $\begin{array}{l}\text { Sugar and } \\
\text { allied industries }\end{array}$ & SUGR & 28 & 27 \\
\hline $\begin{array}{l}\text { Synthetic and } \\
\text { Rayon }\end{array}$ & SYAR & 10 & 7 \\
\hline $\begin{array}{l}\text { Technology and } \\
\text { communication }\end{array}$ & TECH & 13 & 11 \\
\hline $\begin{array}{l}\text { Textile compos- } \\
\text { ite }\end{array}$ & TEXC & 53 & 40 \\
\hline Textile spinning & TEXS & 67 & 60 \\
\hline Textile weaving & TEXW & 11 & 9 \\
\hline Tobacco & TOBC & 3 & 3 \\
\hline Transport & TRNS & 5 & 4 \\
\hline $\begin{array}{l}\text { Vanaspati \& } \\
\text { Allied Industries }\end{array}$ & VAAI & 2 & 2 \\
\hline Woolen & WOOL & 2 & 2 \\
\hline $\begin{array}{l}\text { Real Estate } \\
\text { Investment Trust }\end{array}$ & REIT & 1 & 0 \\
\hline
\end{tabular}

Business Review: (2021) 16(2):1-20 